cargo steamers in the most rapid and efficient manner possible.

Mr. Cunningham has therefore had unrivalled opportunities of acquiring both a theoretical and practical knowledge of dock construction, and in the volume now under notice he has brought together in a concise and well organised form the results of the knowledge thus acquired. The author has not, however, relied solely on his own experience, but has freely made use of the information contained in the numerous papers on dock matters contributed to the Proceedings of the Institution of Civil Engineers and to the numerous reports of the International Navigation Congresses and other technical societies. Of these he has evidently been a diligent reader, as few points of interest in the Proceedings of the societies or in the technical journals that have been dealt with during the last few years seem to have escaped his notice.

While the study of this book may be regarded as essential to the younger engineers engaged in dock work, it will be invaluable as a book of reference to the expert engaged in this branch of engineering and its cognate interests.

The book is divided into twelve chapters, dealing in an exhaustive manner with the designing and construction of docks, the materials and plant required, the theory of construction of the walls and gates, the equipment and working of docks when constructed the appliances required for the handling and transport of cargoes to and from the docks, and for repairing the vessels. The book is well illustrated, there being no less than 34 folding plates and 468 illustrations in the text. The book does great credit both to the author and to the publisher, but, of course, the greatest merit belongs to the former for having furnished the dock engineer with such a valuable aid to his work.

Electric Lighting and Power Distribution. Vol. ii. By W. P. Maycock, M.I.E.E. Pp. xxii +684 . (London: Whittaker and Co, 1903.) Price $7 s .6 d$.

THis little book covers a very great deal of ground, so that it is hardly necessary to say that no subject is discussed in any great detail. The opening chapters deal with dynamos, alternating currents and alternators, and these are followed by a chapter on electricity meters, in which most of the leading types are described and illustrated. The next chapter deals with motors; a dozen pages in this chapter are all that are devoted to electric tramways and railways, which will give some idea of the amount of consideration which each branch receives. Other chapters deal with batteries, transformers, and generating stations. The treatment throughout is of a very elementary character, but the descriptions are clear and concise, and the illustrations well selected and very clearly reproduced, so that the book should be of service to the student for the City Guilds and similar technological examinations, for whom it is primarily intended.

Builders' Quantities. By Herbert C. Grubb. Pp. viii +227 . (London: Methuen and Co., I904.)

Price $4 s .6 d$.

THIs book has been prepared more particularly for the use of candidates studying for the examination in builders' quantities held by the City and Guilds of London Institute. The modes of measurement and examples of "taking off " are given in order for the work of all the trades employed in the erection and completion of a building; and these sections are followed by explanations of squaring dimensions, abstracting, and billing. The text is illustrated by seventy-seven figures.

No. 1803 , VOL. 70]
LETTERS TO THE EDITUR.

[The Editor does not hold himself responsible for opinions expressed by his correspondents. Neither can he undertake to return, or to correspond with the writers of, rejected manuscripts intended for this or any other part of NATURE. No notice is taken of anonymous communications.]

\section{The Origin of the Horse.}

THE receipt of a copy of Prof. J. C. Ewart's admirable paper on "The Multiple Origin of Horses and Ponies" suggests a few remarks. The paper in question is from the Transactions of the Highland and Agricultural Society of Scotland, 1904-one could wish that it had appeared in a publication which comes more regularly under the notice of zoologists. In a previous paper (Proc. Roy. Soc. Edinburgh, 1903) Prof. Ewart had shown conclusively that Equus prjevalskii was not a hybrid between the kiang and the common horse, and had arrived at the conclusion that it might very well rank as a valid species. Lydekker in 1902 had proposed to regard E. prjevalskii (or przewalskii) as a subspecies of $E$. caballus, and now Prof. Ewart does the same, while recognising also two other subspecies, E. c. typicus and E. c. celticus. The animal named typicus is the Norse horse, which is arbitrarily selected as the type of the Linnean caballus. The Celtic pony, still surviving in the pure state in Iceland, is given the new name E. c. celticus. In its way, Prof. Ewart's demonstration of the distinctive characters of this animal deserves to rank with Darwin's treatise on the primrose, as an example of genius applied to common things. The case is so clear that the author himself is evidently half inclined to regard the Celtic pony as a valid species, and it seems to me that the facts justify us in recognising three species of living horses, E. prjevalskii (Poliakoff), E. celticus (Ewart) and E. caballus (L.). The indications are that these animals were quite distinct in the wild state, and the fact that various blends between caballus and celticus exist in domestication is no more proof of specific identity than the same sort of thing is among the dogs, which nobody doubts to have originated from more than one wild species.

The use Prof. Ewart makes of the prehistoric cave drawings of horses is most suggestive. Possibly these sketches may have been taken a little too seriously in some instances, too little allowance being made for eccentricities in drawing. Fig. 27, from the Kesserloch cave, has a remarkably long body, and one might joyfully recognise the Equus scotti, Gidley, were it not that that animal inhabited the plains of Texas and New Mexico. ${ }^{k}$ Prof. Ewart accepts the opinion that the living American horses are wholly of Transatiantic origin. While this is probably correct, I was surprised on looking into the matter a few years ago to find that the evidence was not so complete as I had supposed. It is said that the natives showed great surprise at the horses of the Spaniards, being evidently unacquainted with the animals. This was to be expected, for if wild horses lived in America at the time of Columbus, they surely were not in the "tierra caliente," but rather to the

1 The New Mexico record is based on a molar tooth found by Miss Ada Springer in the Pleistocene beds of the Arroyo Pecos, Las Vegas, and examined by the writer. It differed in no respect from Gidley's description and figure. Mr. Gidley kindly made for me a number of skull-measurements from the types of $E$. scotti, and I found upon comparisons that the five specimens were much more uniform than a similar series of $E$. caballus picked at random would be. This may be attributed no doubt to the greater uniformity of the wild species, but also to these particular specimens being apparently (from the circumstances of their discovery) members of the same herd. The skulls were 57 I to $590 \mathrm{~mm}$. long, and differed from any
sam caballus of which I had measurements in ( $\mathrm{s}$ ) the rather longer muzzle, with the upper dental series (molars and premolars) considerably Jonger, r 95 to $204 \mathrm{~mm}$., and (2) apparently in the greater breadth between the orbits above, but Mr. Gidley afterwards wrote that he found that while the breadth between the anterior borders of the orbits of scotti is slightly greater than in large skulls of caballus, the breadth between the posterior borders is less; hence it would seem that the eyes of scotti looked less for ward than those of caballus. The other measurements :-zygomatic breadth, greatest breadth of muzzle, least breadth of palate, distance between molars of opposite sides, and the greatest breadth of posterior nares, all fall within the limits of variation of $E$. caballus. Hence it is apparent that $E$. scott was in many respects similar to caballus, as Mr. Gidley indicated in his paper on the subject. The bones other than the skuli, taken separately. could not be distinguished from those of caballuts. Other differences in th skulls than those mentioned have been fully described and illustrated by $\mathrm{Mr}$. Gidley, and the facts need not be repeated. No doubt a more minute study of the osteological characters of fossil horses would throw valuable sight on the significance of variations in the living forms. 